\title{
Leaching of Valuable Metals from Orimulsion Burning Ash with Hydrogen Peroxide
}

\author{
by Naganori ROKUKAWA ${ }^{1}$
}

1. Material Processing Dept., National Institute for Resources and Environment, Onogawa, Tsukuba 305

The leaching of valuable metals from orimulsion burning ash collected from electro-precipitator of power plants was carried out by using aqueous hydrogen peroxide solutions. In the leaching using only water, the extraction fraction of vanadium and nickel was low in the water leaching. On the other hand, in the hydrogen peroxide leaching, the extraction fraction of vanadium and nickel increased with an increasing in the concentration of hydrogen peroxide. For instance, the extraction percentage of the metallic components on leaching for 60 minutes at $25{ }^{\circ} \mathrm{C}$ and $\mathrm{pH} 2$ with $2 \% \mathrm{H}_{2} \mathrm{O}_{2}$ solution were $98.8 \%$ for $\mathrm{V}, 98.9 \%$ for $\mathrm{Ni}, 99.2 \%$ for $\mathrm{Mg}$ and $99.2 \%$ for $\mathrm{Ca}$, respectively. Vanadium, nickel, magnesium and calcium were effectively extracted from the orimulsion burning ash with weak acidic solutions containing hydrogen peroxide.

KEY WORDS : Orimulsion, Burning Ash, Vanadium, Nickel, Magnesium, Hydrogen Peroxide

\section{1.はじめに}

オリマルジョンとは，南米のベネズエラの中部を流れるオリノ コ川の北部流域に広く賦存する天然アスファルトのオリノコター ルに水と界面活性剂を加えてエマルジョン化したものである1)。

オリマルジョンはオリノコタールの推定埋蔵量が 1 兆 2,000 億 バーレル (可採埋蔵量, 2,670 億バーレル) と膨大である ${ }^{1)-4)}$ とおよびC 重油に近い流動特性を有していることから，主に火 力発電所のボイラ用燃料として導入 ${ }^{2) 3}$ されれつある。

また，オリマルジョンには，バナジウム，ニッケルなどの金属 成分が含まれていることから，オリマルジョン燃焼灰はバナジウ ムおよびニッケルの資源として期待される。

オリマルジョン燃焼灰からバナジウムおよびニッケルなどの金 属成分を回収をする方法については，オリマルジョン燃焼灰の組 成等が重油燃焼灰に類似していることから，重油燃焼灰の処理法 が適用できるであろうと推定される。しかし，重油燃焼灰からの 金属成分の浸出については，重油燃焼灰にソーダ灰を加えて酸化 焙焼し，バナジウムを可溶性塩に変えて温水で浸出する方法 ${ }^{5)}$ よび水に可溶な金属塩のみを水浸出する方法が実施されている4) にすぎない。

著者は，オリマルジョン燃焼灰からバナジウム，ニッケル等の 有価金属の回収を目的として, 過酸化水素によるオリマルジョン

* 1997 年 7 月 29 日受付 10 月 31 日受理 資源・素材学会 1995 年度春季大 会にて一部発表

1. 正会員 資源環境技術総合研究所素材資源部

〔著者連絡先〕 FAX 0298-58-8458（資環研・素材資源部）

キーワード:オリマルジョン，然狫灰，バナジウム，ニッケル，マグネシウム， 過酸化水素
燃焼灰からの有価金属の浸出について検討したので，その結果に ついて報告する。

\section{2. 実 験 方 法}

\section{$2 \cdot 1$ 試料}

実験に用いた試料は，火力発電所のオリマルジョン専焼ボイラ の電気集塵器から排出されたもので, 密度 $2.45 \mathrm{~g} / \mathrm{cm}^{3}$ (かさ密 度 $0.12 \mathrm{~g} / \mathrm{cm}^{3}$ ) の灰白色をした飛散灰であり, 主な成分の化学 分析值を Table 1 に示す。

オリマルジョン燃焼灰は重油燃焼灰に比べて ${ }^{6)}$, バナジウム, ニッケル执よびマグネシウムの含有率が高く，その中のバナジウ ムとニッケルはオリノコタールから, マグネシウムはエマルジョ ンの安定化㧍よび高温腐食防止のために添加されたものである。 なお，アンモニウム塩はボイラと電気集塵器との間の煙道におい て亜硫酸ガスを捕捉するためにアンモニアの注入によるものであ る。

オリマルジョン燃焼灰の X 線回折図を Fig. 1 に示す。オリマル ジョン燃焼灰中の化合物の形態については，燃焼条件等により異 なるものと考えられるが, 本試料については, X 線回折線から コンピュータ検索により推定された化合物は, $\left(\mathrm{NH}_{4}\right)_{2} \mathrm{Mg}\left(\mathrm{SO}_{4}\right)_{2}$.

Table 1 Chemical analysis of orimulsion burning ash.

(wt \%)

\begin{tabular}{c|c|c|c|c|c|c}
\hline $\mathrm{V}$ & $\mathrm{Ni}$ & $\mathrm{Fe}$ & $\mathrm{Mg}$ & $\mathrm{Ca}$ & $\mathrm{NH}_{4}$ & $\mathrm{SO}_{4}$ \\
\hline 6.94 & 1.62 & 0.20 & 6.30 & 0.93 & 7.68 & 57.4 \\
\hline
\end{tabular}




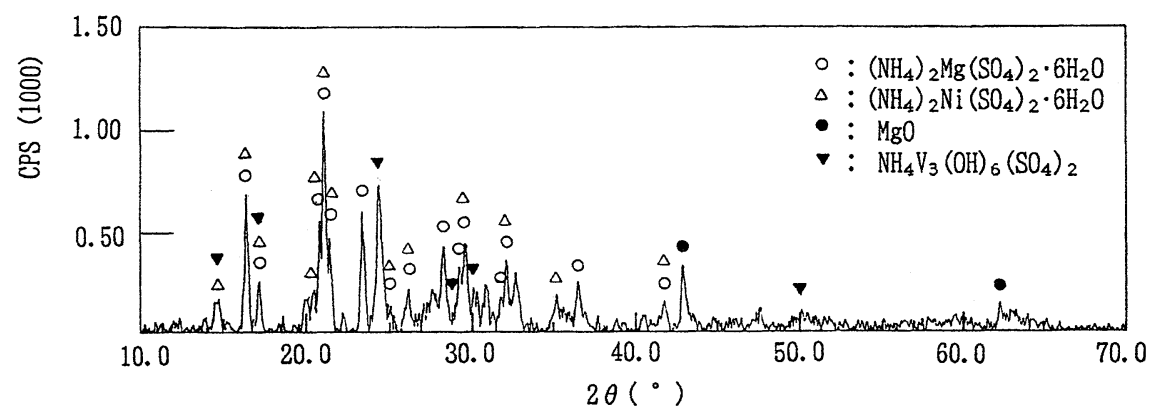

Fig. 1 X-ray diffraction patterns of orimulsion burning ash. (CuK $\alpha, 40 \mathrm{KV}, 20 \mathrm{~mA}$ )

$6 \mathrm{H}_{2} \mathrm{O}$ (JCPDSカードNo. 35-771), $\left(\mathrm{NH}_{4}\right)_{2} \mathrm{Ni}\left(\mathrm{SO}_{4}\right)_{2} \cdot 6 \mathrm{H}_{2} \mathrm{O}$ (12454), $\mathrm{MgO}$ (4-829) および $\mathrm{NH}_{4} \mathrm{~V}_{3}(\mathrm{OH})_{6}\left(\mathrm{SO}_{4}\right)_{2}$ (33-91) であっ た。なお，Fig. 1 には示してないが, $\left(\mathrm{NH}_{4}\right)_{2} \mathrm{Fe}\left(\mathrm{SO}_{4}\right)_{2} \cdot 6 \mathrm{H}_{2} \mathrm{O}$ (35-764), $\mathrm{MgSO}_{4} \cdot 7 \mathrm{H}_{2} \mathrm{O}(36-419), \mathrm{VOSO}_{4} \cdot 5 \mathrm{H}_{2} \mathrm{O}$ (33-1448), $\mathrm{NiSO}_{4} \cdot 4 \mathrm{H}_{2} \mathrm{O}$ (19-843) などの化合物も推定された。

\section{$2 \cdot 2$ 浸出液の調製}

試薬はすべて市販の特級のものを用い，溶液の調製，水浸出等 には蒸留水を使用した。所定濃度の過酸化水素溶液は浸出実験の 直前に調製し, 浸出液の $\mathrm{pH}$ 調整は種々の濃度の硫酸により低 $\mathrm{pH}$ ほど高濃度の酸を用いて行い, $\mathrm{pH}$ 調整剤の影響についての 浸出液のみそれぞれの酸により行った。

なお, 過酸化水素による浸出時間, 浸出温度, 過酸化水素濃度 および固液濃度の影響についての浸出実験では $\mathrm{pH}$ 調整は行わな かった。

\section{$2 \cdot 3$ 浸出}

浸出試験は容量 $100 \mathrm{~cm}^{3}$ の硬質の広口ガラス瓶に試料を採取 し, 浸出液を所定量添加して, 容器を所定温度に調節した恒温水 槽に入れ，マグネチックスターラにより所定時間 $400 \mathrm{rpm}$ (長さ $30 \mathrm{~mm}$, 高さ $7.5 \mathrm{~mm}$ のオクタゴン型攪找子）で攪挥後, $\mathrm{pH}$ を 測定し, 万過後, 万液抒よび浸出残渣を分析して各金属成分の浸 出率を求めた。

なお，金属成分の定量は ICP 発光分光装置で, $\mathrm{NH}_{4}{ }^{+}$および $\mathrm{SO}_{4}{ }^{2-}$ イオンの定量はイオンクロマトグラフ装置により行った。

\section{3. 結果および考察}

固液濃度 $20 \mathrm{~g} / \mathrm{dm}^{3}, 25{ }^{\circ} \mathrm{C}$ で $60 \mathrm{~min}$ 水浸出したときのバナジ ウム，ニッケル，マグネシウム，カルシウム拉よび鉄の浸出率は それぞれ $37.6 \%$ ， $41.5 \% ， 12.2 \% ， 40.8 \%$ および $26.9 \%$ といず れの成分も浸出率は $50 \%$ 未満で, 浸出後の $\mathrm{pH}$ は 3.54 であった。
一方, 水浸出と同様に $\mathrm{pH} 4.94$ の $2 \%$ 過酸化水素 $\left(\mathrm{H}_{2} \mathrm{O}_{2}\right)$ 水溶 液で浸出したときのバナジウム, ニッケル, マグネシウム, カル シウムおよび鉄の浸出率はそれぞれ $95.8 \% ， 96.5 \% ， 98.9 \%$ ， $99.1 \%$ および $80.7 \%$ で, 浸出後の $\mathrm{pH}$ は 2.48 であった。過酸化 水素水溶液で浸出することにより, 各金属成分の浸出率は著しく 向上したことから過酸化水素水溶液による浸出を検討した。

\section{$3 \cdot 1$ 浸出時間の影響}

$\mathrm{pH} 5.20$ の $1 \% \mathrm{H}_{2} \mathrm{O}_{2}$ 溶液により固液濃度 $10 \mathrm{~g} / \mathrm{dm}^{3}, 25{ }^{\circ} \mathrm{C} て ゙$ 浸出したときの浸出時間とバナジウムおよびニッケルの浸出率の 関係をFig. 2 に示す。バナジウムとニッケルの浸出率は浸出時 間 $5 \mathrm{~min}$ で $97.4 \%$ と $95.9 \%$ で, $120 \mathrm{~min}$ との浸出率の差はバナ ジウムニッケルとも $1 \%$ 以下であった。

なお, 浸出後の $\mathrm{pH}$ は浸出時間 $5 \mathrm{~min}$ から $120 \mathrm{~min}$ の範囲で は 2.65 と一定で, 浸出時間による浸出後の $\mathrm{pH}$ 差はなかった。

\section{$3 \cdot 2$ 浸出温度の影響}

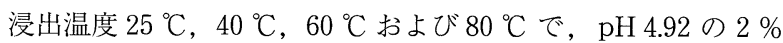
$\mathrm{H}_{2} \mathrm{O}_{2}$ 溶液により固液濃度 $10 \mathrm{~g} / \mathrm{dm}^{3}$ で, $60 \mathrm{~min}$ 浸出したときの 浸出温度の影響について検討した。

$25{ }^{\circ} \mathrm{C}$ でのバナジウムとニッケル浸出率は $98.4 \%$ と $96.9 \%$ で， 浸出温度が高くなるに従ってバナジウムとニッケルの浸出率は低 下し, $80{ }^{\circ} \mathrm{C}$ では $93.7 \%$ と $90.8 \%$ となり, $25{ }^{\circ} \mathrm{C}$ と $80{ }^{\circ} \mathrm{C}$ との浸 出率の差はバナジウムが $4.2 \%$ ，ニッケルが $4.3 \%$ であった。浸 出温度は常温で十分であるものと考えられる。なお，浸出後の $\mathrm{pH}$ は $25{ }^{\circ} \mathrm{C}$ で $2.64,80{ }^{\circ} \mathrm{C}$ で 4.05 であった。

\section{$3 \cdot 3$ 過酸化水素濃度の影響}

種々の濃度の過酸化水素水溶液により, 固液濃度 $10 \mathrm{~g} / \mathrm{dm}^{3}$, $25{ }^{\circ} \mathrm{C}$ で $60 \mathrm{~min}$ 浸出したときの過酸化水素濃度と浸出率の関係 をFig. 3 に示す。

バナジウムおよびニッケルの浸出率は, $\mathrm{H}_{2} \mathrm{O}_{2}$ 濃度が高くなる

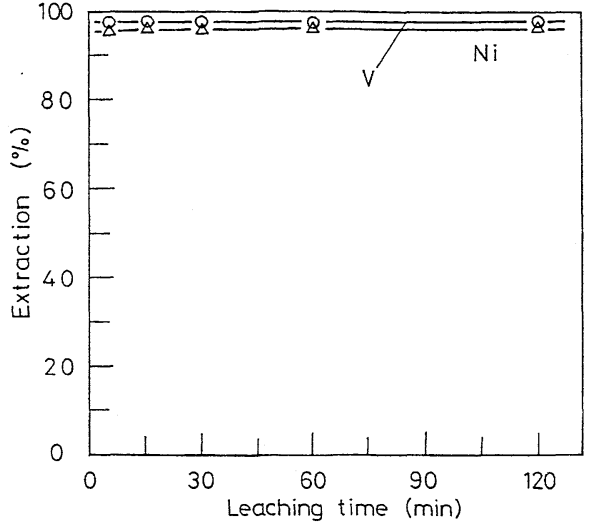

Fig. 2 Effect of leaching time. Solid-liquid density : $10 \mathrm{~g} / \mathrm{dm}^{3}, \mathrm{H}_{2} \mathrm{O}_{2}$ conc. : $1 \%$, Leaching temp. : $25^{\circ} \mathrm{C}$

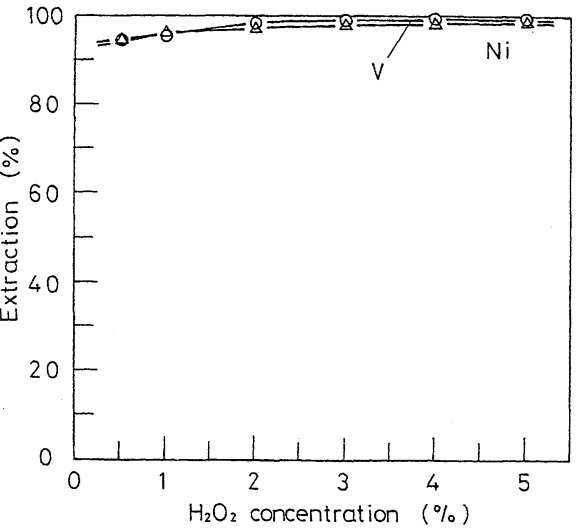

Fig. 3 Effect of hydrogen peroxide concentration. Solid-liquid density : $10 \mathrm{~g} / \mathrm{dm}^{3}$, Leaching temp. : 25 ${ }^{\circ} \mathrm{C}$, Time : $60 \mathrm{~min}$ 


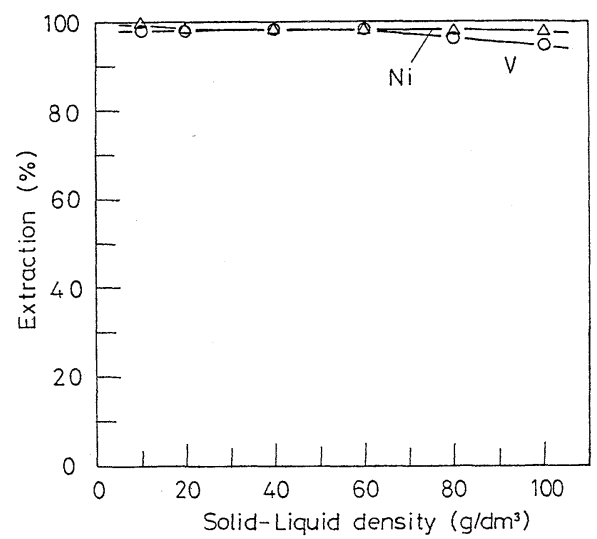

Fig. 4 Effect of solid-liquid density.

$\mathrm{H}_{2} \mathrm{O}_{2}$ conc. : $4 \%$, leaching temp. : $25^{\circ} \mathrm{C}$, Time : $60 \mathrm{~min}$

に従って増加し， $5 \% \mathrm{H}_{2} \mathrm{O}_{2}$ 濃度では $99.3 \%$ および $98.8 \%$ とな り，浸出液の $\mathrm{pH}$ は 2.55 であった。なお，Fig. 3 には示してない がマグネシウム拉よびカルシウムの浸出率はいずれの過酸化水素 濃度においても，バナジウムの浸出率よりも高かった。

\section{$3 \cdot 4$ 固液濃度の影響}

$\mathrm{pH} 4.63$ の $4 \mathrm{H}_{2} \mathrm{O}_{2}$ 溶液により $25^{\circ} \mathrm{C}$ で $60 \mathrm{~min}$ 浸出したとき の固液濃度と浸出率の関係を Fig. 4 に示す。

バナジウムおよびニッケル浸出率は固液濃度が高くなるに従っ て低下したが, 固液濃度 $10 \mathrm{~g} / \mathrm{dm}^{3}$ と $100 \mathrm{~g} / \mathrm{dm}^{3}$ とのバナジウム とニッケルの浸出率の差はそれぞれ $3.9 \%$ と $1.8 \%$ であり，固液 濃度の影響はバナジウムに比べてニッケルの方が少なかった。な お, 固液濃度 $60 \mathrm{~g} / \mathrm{dm}^{3}$ でのバナジウムとニッケルの浸出率は $98.7 \%$ と $98.0 \%$ であった。

一方, 浸出液の $\mathrm{pH}$ は固液濃度 $10 \mathrm{~g} / \mathrm{dm}^{3}$ で $2.59,100 \mathrm{~g} / \mathrm{dm}^{3}$ で 1.96 と固液濃度が高くなるに従って低下した。

\section{$3 \cdot 5 \mathrm{pH}$ の影響}

固液濃度 $10 \mathrm{~g} / \mathrm{dm}^{3}$ で $60 \mathrm{~min}$ 浸出したときの浸出後の $\mathrm{pH}$ と バナジウム，ニッケルおよびマグネシウムの浸出率の関係をそれ ぞれFig. 5, Fig.6 およびFig. 7 に示す。

過酸化水素を含む弱酸性溶液による浸出では硫酸酸性の弱酸性

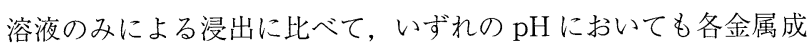
分の浸出率は高くなった。pH が高くなるに従って過酸化水素に よる効果は大きくなり, pH 2.5 での $2 \%$ 過酸化水素水溶液によ る浸出では pH 2.5 の水溶液のみの浸出に比べてバナジウムが 54 \%, ニッケルが $13 \%$ ，マグネシウムが 8 \% 浸出率が高くなり, いずれの浸出率も $95 \%$ 以上となった。

オリマルジョン燃焼灰を過酸化水素水溶液で浸出することによ り，バナジウムをすべて 5 価のイオンで浸出することが可能であ るため, 浸出液からのバナジウムの回収において酸化処理工程を 省くことができるものと考えられる。なお， $2 \%$ の過酸化水素を 含む $\mathrm{pH} 2.0$ の溶液で浸出したときのバナジウム，ニッケルおよ びマグネシウムの浸出率はそれぞれ $98.9 \% ， 99.2 \%$ および 99.4 \%であった。

\section{$3 \cdot 6 \mathrm{pH}$ 調整剤の影響}

オリマルジョン燃焼灰から有価金属を効率よく浸出するために は, 浸出液の $\mathrm{pH}$ を調整する必要があり, $\mathrm{pH}$ 調整剤として塩酸, 硫酸および硝酸を用いて，それぞれの酸で種々の $\mathrm{pH}$ に調整した 溶液抢よび種々の $\mathrm{pH}$ に調整した $2 \%$ の過酸化水素水溶液によ り，それぞれ固液濃度 $10 \mathrm{~g} / \mathrm{dm}^{3}, 25{ }^{\circ} \mathrm{C}$ で $60 \mathrm{~min}$ 浸出した。

その結果, バナジウム, ニッケルおよびマグネシウムは, 塩酸,

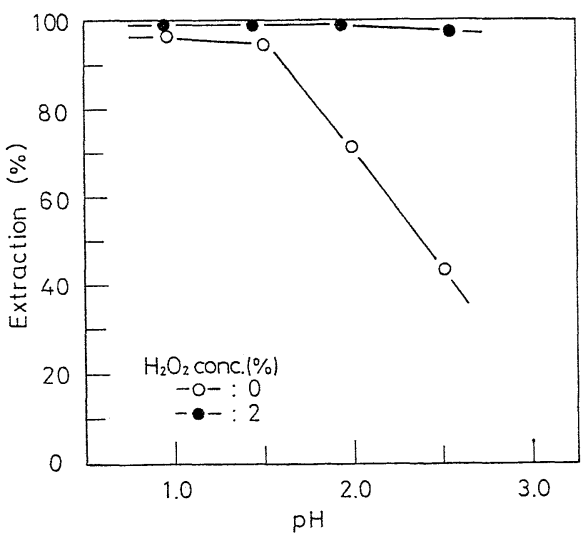

Fig. 5 Relationship between extraction of vanadium and $\mathrm{pH}$ Solid-liquid density : $10 \mathrm{~g} / \mathrm{dm}^{3}$, Leaching temp. : $25^{\circ} \mathrm{C}$, Time : $60 \mathrm{~min}$

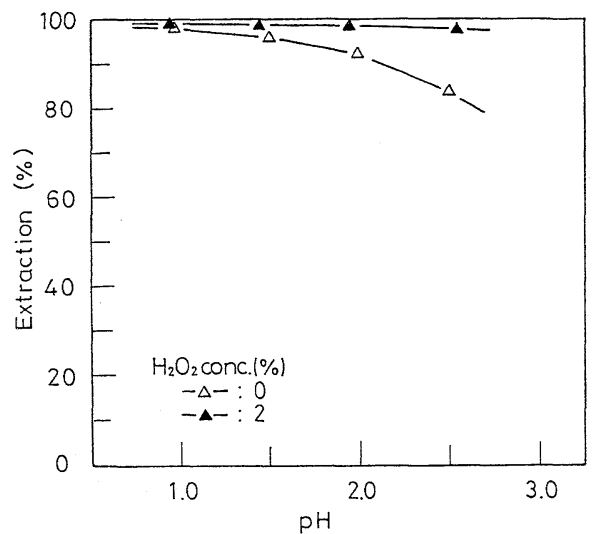

Fig. 6 Relationship between extraction of nickel and $\mathrm{pH}$. Solid-liquid density : $10 \mathrm{~g} / \mathrm{dm}^{3}$, Leaching temp. : $25^{\circ} \mathrm{C}$, Time : $60 \mathrm{~min}$

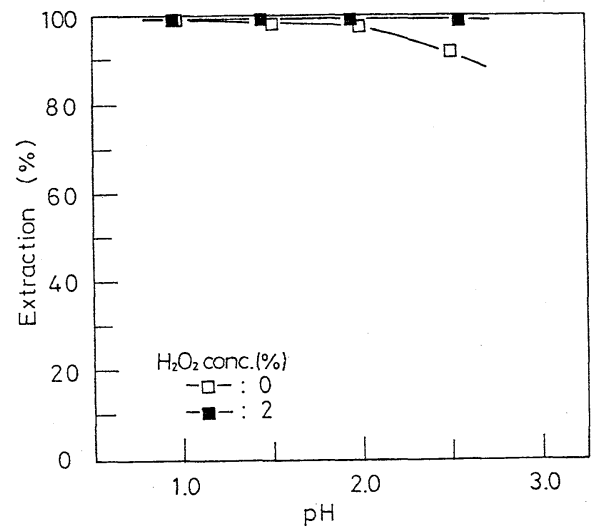

Fig. 7 Relationship between extraction of magnesium and $\mathrm{pH}$. Solid-liquid density : $10 \mathrm{~g} / \mathrm{dm}^{3}$, Leaching temp. : $25^{\circ} \mathrm{C}$ Time : $60 \mathrm{~min}$

硫酸および硝酸のいずれの溶液においてもほぼ同じような浸出傾 向を示し，酸の種類による各金属成分の浸出率の差はほとんどな かった。また，過酸化水素を含む水溶液での浸出においてもほぼ 同様であった。

オリマルジョン燃焼灰には多量の硫酸塩が含まれており, 浸出 液には硫酸イオンが溶解してくることから，後処理のことを考慮 すれば， $\mathrm{pH}$ 調整剤としては硫酸が有効であるものと考えられる。 


\section{4. 結 論}

オリマルジョン燃焼灰からの有価金属の浸出を目的として，過 酸化水素水溶液による浸出を検討した結果, $\mathrm{pH} 2$ の $2 \%$ 過酸化 水素水溶液により, $25{ }^{\circ} \mathrm{C}$ で $60 \mathrm{~min}$ 浸出したときのバナジウム, ニッケルおよびマグネシウムの浸出率はいずれも $98 \%$ 以上であっ た。オリマルジョン燃焼灰を過酸化水素を含む弱酸性溶液で浸出 することにより，オリマルジョン燃焼灰からバナジウム，ニッケ ルおよびマグネシウムを効率よく浸出することが可能であった。 また，浸出液の $\mathrm{pH}$ の調整に使用する酸は硫酸，塩酸および硝 酸のいずれもほぼ同じ抽出傾向を示した。オリマルジョン燃焼灰
の浸出液には硫酸イオンが溶解してくることから, 後処理のこと を考慮すれば，浸出液の $\mathrm{pH}$ の調整に使用する酸は硫酸が有効で あるものと考えられる。

なお，オリマルジョン燃焼灰は, 三菱化学(株)のご厚意により ·提供していただいたもので，ここに深く感謝の意を表する。

\section{引用 文 献}

1）豊田隆治·中鸠靖史：火力原子力発電，Vol. 42， p. 176-180，(1990）

2）高松宏至：PETROTCH, Vol. 16, p. 1094-1098, (1990)

3）竹本克己：エネルギー・資源，Vol. 15，p. 229-234，(1994)

4）佐藤完二：工業レアメタル，No. 106, p. 30-33, (1993)

5）富田正夫：工業レアメタル，Vol. 65, p. 94-95，(1978)

6）六川暢了：資源处理技術, Vol. 37, p. 63-69, (1990) 